\title{
Rasio Jumlah Realisasi Penerimaan PPN Terhadap Total Realisasi Penerimaan Pajak (Pada KKP Pratama Sukabumi)
}

\author{
Dicki Prayudi ${ }^{1}$, Anisa Sejati ${ }^{2}$ \\ ${ }^{1}$ Universitas Bina Sarana Informatika \\ dicki.dcd@bsi.ac.id \\ ${ }^{2}$ STIE PGRI Sukabumi \\ anisasejati1993@gmail.com
}

(Prayudi \& Sejati, 2019)

Prayudi, D., \& Sejati, A. (2019). Rasio Jumlah Realisasi Penerimaan PPN Terhadap Total Realisasi Penerimaan Pajak (Pada KKP Pratama Sukabumi). Moneter, 6(2), 17-24.

\begin{abstract}
A Tax is the main source of state income in addition to various other income. Aside from being a source of state revenue, taxes also function as policy instruments used by the government to reduce consumption of public goods and services. Value Added Tax (VAT) is one type of tax that has a large income potential. This study aims to determine how much contribution is given by Value Added Tax to the total realization of tax revenue at the Sukabumi Tax Office. This study uses a horizontal and vertical analysis method with added literature from the literature study. That to suppress the instability of tax revenues, the Pratama Sukabumi Tax Service Office breaks down all revenue targets. Therefore, strategic steps need to be taken to keep achieving the specified targets. Among them is by disseminating new regulations, as well as guidance and ongoing consultation. It is expected that the tax target can be increased every year. As a result, Comparative Analysis of the Amount of Realization of Value Added Tax Revenues with Total Realization of Tax Revenues As a basis for Assessing Achievement for 5 years is $28.99 \%$, which means that $28.99 \%$ of tax revenues are contributions or revenues from Value Added Tax.
\end{abstract}

Keywords: Tax, Value Added tax, Tax Revenue Ratio.

\section{PENDAHULUAN}

Pembangunan Nasional merupakan kegiatan yang berlangsung terus menerus dan berkesinambungan yang secara umum bertujuan untuk meningkatkan kesejahteraan rakyat baik material maupun spiritual, untuk dapat merealisasikan tujuan tersebut, Pemerintah perlu melaksanakan pembangunan disegala bidang, baik itu bidang politik, ekonomi, sosial, budaya, pertahanan dan keamanan. Tujuan utama dari pembangunan ekonomi adalah mencapai kondisi masyarakat yang sejahtera. Untuk mencapai tujuan utama, pembangunan ekonomi itu pemerintah berusaha meningkatkan pendapatan nasional.

Kemampuan menggali dana baik domestik maupun luar negri dalam pelaksanaan pembangunan disegala bidang perlu terus ditingkatkan. Hal ini berkaitan dengan upaya perwujudan kemandirian pembiayaan pembangunan. Salah satu usaha untuk mewujudkan kemandirian pembiayaan pembangunan yaitu dengan menggali sumber dana yang berasal dari dalam negeri berupa pajak.
Potensi penerimaan pajak sangat berpengaruh dalam mensukseskan pembangunan nasional, menyadari hal ini sangat diperlukan kesadaran dari seluruh lapisan masyarakat untuk turut mensukseskan peningkatan penerimaan pajak dengan cara menjalani kewajiban mereka dengan benar dan tepat waktu. Pencapaian tujuan tersebut diperlukan adanya kerja sama antara pemerintah dengan masyarakat (Anam \& Andini, 2016).

Salah satu jenis pajak yang dipungut di Indonesia dan memberikan kontribusi yang cukup besar adalah Pajak pertambahan Nilai. Saat ini PPN memiliki peranan yang strategis dan signifikan dalam porsi penerimaan negara dari sektor perpajakan. PPN merupakan pajak yang dipungut oleh Pemerintah Pusat yang merupakan pengganti dari Pajak Penjualan (Rambitan, 2019). Untuk mendukung kebijakan pemerintah dan Direktorat Jendral Pajak dalam sektor pajak perlu adanya kesadaran dan kepedulian masyarakat atas pajak serta program perpajakan seperti sosialisasi pajak, penegakan hukum serta sanksi perpajakan. Penerimaan pajak di kantor pelayanan pajak sari sektor pajak pertambahan nilai selama beberapa tahun ini tidak mencapai target, realisasi penerimaan pajak 
pertambahan nilai pun mengalami penurunan. Oleh karena itu pemerintah bersifat keras dan tegas dalam kewenangannya sebagai pengawas dan pemeriksa terhadap pelaksanaan kewajiban perpajakan yang dilakukan oleh wajib pajak. Beberapa upaya dilakukan, salah satunya dengan menerbitkan UU No. 42 Tahun 2009 Tentang Pajak Pertambahan Nilai. Masalah kemudian timbul akibat penurunan jumlah penerimaan pajak dari sektor pertambahan nilai ini sehingga rasio terhadap total penerimaan pajak dinilai tidak memuaskan.

Kantor Pelayanan Pajak (KPP) Pratama Sukabumi merupakan kantor pelayanan pajak yang bergerak di bidang penerimaan pajak. Sebagai instansi berkewajiban yntuk melakukan perhitungan dan pelaporan pajak sesuai ketentuan yang mengacu pada Undang-undang Perpajakan yang berlaku. Kantor Pelayanan Pajak (KPP) Pratama Sukabumi adalah salah satu instansi vertikal Direktorat Jenderal Pajak yang mempunyai tugas melaksanakan penyuluhan, pelayanan, dan pengawasan Wajib Pajak di bidang Pajak Penghasilan, Pajak Pertambahan Nilai, Pajak Penjualan atas Barang Mewah, Pajak Tidak Langsung Lainnya, Pajak Bumi dan Bangunan serta Bea Perolehan Hak atas Tanah dan Bangunan dalam wilayah wewenangnya berdasarkan peraturan perundang-undangan yang berlaku.

Kantor Pelayanan Pajak (KPP) Pratama Sukabumi berlokasi di Jalan Laksamana RE Martadinata No. 1 Sukabumi, pada awal terbentuknya merupakan penggabungan dari Kantor Pelayanan Pajak Sukabumi dengan Kantor Pelayanan Pajak Bumi dan Bangunan Sukabumi (sesuai dengan Peraturan Menteri Keuangan Nomor 132/PMK.01/2006 tentang Organisasi dan Tata Kerja Instansi Vertikal Direktorat Jenderal Pajak STDD Peraturan Menteri Keuangan sebagaimana telah diubah terakhir dengan nomor 167/PMK.01/2012).

Pengertian pajak menurut Undang-undang Nomor 28 tahun 2007 tentang Ketentuan Umum Dan Tata Cara Perpajakan (UU KUP) adalah kontribusi wajib kepada negara yang terutang oleh orang pribadi atau badan yang bersifat memaksa berdasarkan UndangUndang, dengan tidak mendapatkan imbalan secara langsung dan digunakan untuk keperluan negara bagi sebesar-besarnya kemakmuran rakyat (Pemerintah Indonesia, 2007). Dalam Undangundang Nomor 28 tahun 2007 pemungutan pajak dikenal beberapa sistem pemungutan yang digunakan sebagai berikut:

\section{Official Assessment System}

Suatu system pemungutan pajak dimana besarnya pajak yang harus dilunasi atau pajak yang terutang oleh wajib pajak ditentukan oleh fiskus dalam hal ini wajib pajak bersifat final.

\section{Sell Assessment System}

Suatu system pemungutan pajak dimana wewenang menghitung besarnya pajak yang terutang oleh wajib pajak diserahkan oleh fiskus kepada wajib pajak yang bersangkutan, dimana dengan system ini wajib pajak harus aktif untuk menghitung, menyetor dan melaporkan kepada Kantor Pelayanan Pajak (KPP) sedangkan fiskus hanya bertugas memberikan penerangan dan pengawasan.

\section{With Holding System}

Suatu cara pemungutan pajak dimana penghitungan besarnya pajak terutang oleh wajib pajak dilakukan oleh pihak ketiga.

Menurut UU No. 42 tahun 2009, “pajak pertambahan nilai adalah pajak yang dikenakan atas konsumsi barang dan jasa didalam daerah pabean yang dikenakan bertingkat setiap jalur produksi dan distribusi”. Juga mengungkapkan pajak pertambahan nilai adalah pajak yang dikenakan atas konsumsi Barang Kena Pajak atau Jasa Kena Pajak didalam daerah Pabean (dalam wilayah Indonesia). Orang pribadi, perusahaan, maupun pemerintah yang mengkonsumsi Barang Kena Pajak atau Jasa Kena Pajak dikenakan PPN. Pada dasarnya, setiap barang dan jasa adalah Barang Kena Pajak atau Jasa Kena Pajak, kecuali ditentukan lain oleh Undang-undang PPN.

Menurut (Sukardji, 2014), Pajak Pertambahan Nilai merupakan Pajak Tidak Langsung Karakter ini memberikan suatu konsekuensi yuridis bahwa antara pemikul beban pajak dengan penanggung jawab atas pembayaran pajak ke Kas Negara berada pada pihak yang berbeda. Pemikul beban pajak ini secara nyata berkedudukan sebagai pembeli Barang Kena Pajak atau Penerima Jasa Kena Pajak. Pajak Pertambahan Nilai dapat dirumuskan berdasarkan dua sudut pandang sebagai berikut:

1. Sudut Pandang Ekonomi, beban pajak dialihkan kepada pihak lain yaitu pihak yang akan mengkonsumsi barang atau jasa yang menjadi objek pajak.

2. Sudut pandang yuridis, tanggung jawab pembayaran pajak kepada kas Negara tidak berada di tangan pihak yang memikul beban pajak. Sudut pandang secara yuridis ini membawa konsekuensi filosofis bahwa dalam Pajak Tidak Langsung apabila pembeli atau penerima jasa, pada hakikatnya sama dengan telah membayar pajak tersebut ke Kas Negara.

3. Pajak Pertambahan Nilai merupakan Pajak Objektif. Yang dimaksud dengan Pajak Objektif adalah suatu jenis pajak yang pada saat 
timbulnya kewajiban pajak ditentukan oleh factor objektif, yaitu adanya taatbestand, adapun yang dimaksud taatbestand adalah keadaan, peristiwa atau perbuatan hukum yang dapat dikenakan pajak yang juga disebut dengan nama Objek Pajak.

4. Multi Stage Levy (Multy Stage Levy Tax) merupakan karakteristik Pajak Pertambahan Nilai yang dikenakan pada setiap mata rantai jalur produksi dan jalur distribusi. Setiap penyerahan barang yang menjadi Objek Pajak Pertambahan Nilai mulai dari tingkat pabrikan (Manufacture) kemudian ditingkat pedagang besar (wholesaler) dalam berbagai bentuk ataupun nama, sampai dengan tingkat pedagang eceran (retailer) dikenakan Pajak Pertambahan Nilai.

5. PPN terutang untuk dibayar ke kas Negara dihitung menggunakan indirect substraction method/credit method/invoice method. Pajak yang dipungut oleh PKP penjual atau pengusaha jasa tidak secara otomatis dibayar ke kas Negara. PPN terutang yang wajib dibayar ke kas Negara merupakan hasil perhitungan mengurangkan PPN yang dibayar kepada PKP lain yang dinamakan pajak masukan (input tax) dengan PPN yang dipungut dari pembeli atau penerima jasa yang dinamakan pajak keluaran (output tax). Pola ini dinamakan metode penguranagan tidak langsung (indirect substraction method). Pajak keluaran yang dikurangkan dengan Pajak Masukannya untuk memperoleh jumlah pajak yang akan dibayarkan ke kas Negara dinamakan tax credit. Atau PPN yang dipungut tidak langsung disetorkan ke Kas Negara. PPN yang disetorkan ke Kas Negara merupakan hasil perhitungan Pajak Masukan dan Pajak Keluaran yang dimana harus ada bukti pungutan PPN berupa Faktur Pajak.

6. Pajak atas Konsumsi Umum Dalam Negeri. Pajak Pertambahan Nilai hanya dikenakan atas Barang atau Jasa Kena Pajak yang dikonsumsi di dalam negeri, termasuk Barang Kena Pajak yang diimpor dari luar negeri. Tetapi untuk ekspor Barang Kena Pajak Tidak dikenakan Pajak Pertambahan Nilai. Prinsip ini menggunakan prinsip tempat tujuan (destination principle) yaitu pajak dikenakan ditempat barang atau jasa akan dikonsumsi.

7. Pajak Pertambahan Nilai bersifat Netral. Netralitas ini dapat dibentuk karena adanya 2 (dua) Faktor, yaitu:

a. PPN dikenakan atas konsumsi barang maupun jasa

b. Pemungutannya menganut prinsip tempat tujuan PPN dipungut ditempat barang/jasa dikonsumsi.
8. Tidak Menimbulkan Dampak Pajak Berganda. Pajak berganda dapat dihindari karena PPN dipungut atas dasar nilai tambah dan PPN yang dibayar diperhitungkan dengan PPN yang dipungut.

Apabila dicermati, subjek PPN tersirat di balik ketentuan yang mengatur tentang objek pajak yaitu Pasal 4 ayat (1), Pasal 16C dan Pasal 16D UU PPN 1984. Dari saduran jurnal sebelumnya (Daud, 2018) , ketiga pasal tersebut dapat diketahui bahwa subjek PPN dapat dikelompokan menjadi dua yaitu PKP dan non PKP. Masing-masing kelompok subjek pajak ini dapat diurai dari pasal-pasal yang terkait sebagai berikut :

1. PKP (Pengusaha Kena Pajak)

Beberapa pasal yang menyiratkan bahwa subjek pajaknya adalah PKP:

a. Pasal 4 ayat (1) huruf a dan huruf c yang menentukan PPN dikenakan atas penyerahan BKP atau JKP

b. Pasal 4 ayat (1) huruf $f$, huruf g, dan huruf h UU PPN 1984 dengan lugas menentukan bahwa PPN dikenakan atas ekspor BKP Berwujud, ekspor BKP tidak berwujud, dan ekspor JKP yang dilakukan oleh PKP.

c. Pasal 16D UU PPN 1984 diawali dengan kalimat, PPn dikenakan atas penyesrahan BKP berupa aktiva yang menurut tujuan semula aktiva tersebut tidak untuk diperjualbelikan oleh PKP.

\section{Non PKP}

Sebutan "non PKP" mengandung pengertian tidak dipersyaratkan memiliki

status PKP supaya dapat melaksanakan kewajiban PPN, seperti yang tersirat dalam:

a. Pasal 4 ayat (1) huruf b menentukan bahwa PPN dikenakan atas impor BKP. Tidak disebut dengan tegas bahwa seseorang atau barang yang menginpor BKP harus berstatus PKP supaya dapat membayar PPN yang terutang.

b. Pasal 4 ayat (1) huruf d dan huruf e menentukan bahwa PPN dikenakan atas pemanfaatan BKP tidak Berwujud atau JKP dari luar daerah pabean.

c. Pasal 16C dengan lugas menentukan bahwa PPN dikenakan atas kegiatan membangun sendiri yang dilakukan tidak dalam kegiatan usaha atau pekerjaannya, baik oleh orang pribadi atau badan.

Saduran (Hasan, 2018) tentang pembayaran PPN menyebutkan tarif pajak pertambahan nilai adalah: 
1. Tarif Pajak Pertambahan Nilai sebesar $10 \%$ (sepuluh persen)

Tarif PPN yang berlaku atas penyerahan BKP dan/atau penyerahaan JKP adalah tarif tunggal, sehingga mudah dalam pelaksanaannya dan tidak memerlukan daftar penggolongan barang atau penggolongan jasa dengan tarif yang berada sebagaimana berlaku pada Pajak Penjualan atas Barang Mewah.

2. Tarif Pajak Pertambahan Nilai atas ekspor Barang Kena Pajak sebesar $0 \%$ (nol persen). Tarif PPN adalah pajak yang dikenakan atas konsumsi Barang Kena Pajak di dalam Daerah Pabean. Oleh karena itu, Barang Kena Pajak yang diekspor atu dikonsumsi di luar Daerah Pabean dikenakan Pajak Pertambahan Nilai dengan tarif 0\% ( nol persen). Tarif Pajak sebagaimana dimaksud pada ayat 1 dapat diubah menjadi serendah-rendahnya $5 \%$ dan setinggitingginya $15 \%$.

\section{METODOLOGI PENELITIAN}

Pada umumnya para fiskus menggunakan konsep perbandingan realisasi sebagai dasar untuk menentukan pendapatan. Karena dengan perbandingan realisasi akan terlihat penurunan atau kenaikan pada kinerja Kantor Pelayanan Pajak Pratama Sukabumi. Penghitungan dengan cara perbandingan ini akan dapat menentukan dengan mudah ukuran presentase dalam sebuah nilai.

Pendapatan yang digunakan oleh Kantor Pelayanan Pajak Pratama Sukabumi adalah pengakuan pendapatan dari penerimaan total penerimaan pajak pertambahan nilai dan total penerimaan pajak. Jadi Kantor Pelayanan Pajak Pratama Sukabumi mencatat laporan keuangan yakni pembayaran pajak pertambahan nilai dari wajib pajak serta penerimaan total penerimaan pajak. Dengan demikian, maka peneliti ingin mengetahui seberapa besarkah kontribusi Pajak Pertambahan Nilai terhadap total penerimaan pajak di Kantor Pelayanan Pajak Pratama Sukabumi akankah kontribusi Pajak Pertambahan Nilai naik atau turun dibandingkan dengan total penerimaan pajak pada Kantor Pelayanan Pajak Pratama Sukabumi.

Jenis data yang digunakan adalah Data Primer dan Data Sekunder. Data Primer berupa data Penerimaan Pajak Pertambahan Nilai dari kuartal 5 tahun dan Data Total penerimaan Pajak di kuartal tahun yang sama. Selain itu, Data Sekunder yang dilakukan adalah Observasi dan wawancara kepada pihak yang bertugas, terkait dengan paparan penerimaan pajak di kuartal tahun yang diteliti.
Dengan menggunakan teknik pengambilan data berupa studi kepustakaan dan studi dokumentasi, dimana jenis penelitiannya adalah kuantitatif dengan pendekatan deskriptif dengan mendeskripsikan dan menganalisis permasalahan yang ada, khususnya mengenai penerimaan salah satu sub pajak. Metode analisis menggunakan analisis horizontal dan analisis vertical (Sugiyono, 2010). Kontribusi PPN terhadap Total penerimaan pajak di KPP Pratama sejauh ini terus mengalami fluktuasi dari tahun ke tahun.

\section{HASIL DAN PEMBAHASAN}

Kantor Pelayanan Pajak (KPP) Pratama Sukabumi adalah salah satu instansi vertikal Direktorat Jenderal Pajak yang mempunyai tugas melaksanakan penyuluhan, pelayanan, dan pengawasan Wajib Pajak di bidang Pajak Penghasilan, Pajak Pertambahan Nilai, Pajak Penjualan atas Barang Mewah, Pajak Tidak Langsung Lainnya, Pajak Bumi dan Bangunan serta Bea Perolehan Hak atas Tanah dan Bangunan dalam wilayah wewenangnya berdasarkan peraturan perundang-undangan yang berlaku. Berikut ini bukti jumlah realisasi penerimaan pajak pertambahan nilai pada KPP Pratama Sukabumi dari tahun 2012 sampai dengan tahun 2016 adalah sebagai berikut:

Tabel 1. Penerimaan Pajak Pertambahan Nilai

\begin{tabular}{ccccc} 
Tahun & $\begin{array}{c}\text { Penerimaan } \\
\text { Netto }\end{array}$ & Target Tahun & Pencapaian & selisih \\
& & & & \\
\hline 2112 & $130,985,026,405$ & $83,626,150,836$ & 156,63 & - \\
\hline 2013 & $175,968,860,919$ & $150,472,082,863$ & 116,94 & 34,34 \\
\hline 2014 & $213,881,719,297$ & $221,675,124,079$ & 96,48 & 21,54 \\
\hline 2015 & $297,014,047,335$ & $337,007,226,139$ & 88,13 & 38,86 \\
\hline 2016 & $315,544,685,539$ & $343,689,551,000$ & 91,81 & 6,23 \\
\hline
\end{tabular}

Sumber: Kantor KKP Pratama Sukabumi (2016)

Rumus yang digunakan untuk mengetahui selisih adalah sebagai berikut:

$\Delta=\underline{X_{2}-X_{1}} \times 100 \%$
$X_{1}$

Sumber: Untung Sukardji (2014)

Rencana target penerimaan PPN tahun 2012 sebesar 83.626.150.836 dan realisasi penerimaan PPN sebesar 130.985.026.405 dengan pencapaian sebesar 156,63\% dan pada tahun 2012 rencana penerimaan PPN dikatakan tercapai. 
1. Rencana target penerimaan PPN tahun 2013 sebesar 150.472.082.863 dan realisasi penerimaan PPN sebesar 175.968.860.919 dengan pencapaian sebesar $116,94 \%$ selisih perbandingan dengan tahun sebelumnya yaitu sebesar 34,34 \% dan dikatakan Penerimaan PPN tercapai.

2. Rencana target penerimaan PPN tahun 2014 sebesar 221.675.124.079 dan realisasi penerimaan PPN sebesar 213.881.719.297 dengan pencapaian sebesar 96,48\% selisih perbandingan dengan tahun sebelumnya yaitu sebesar 21,54\% dan pada tahun 2014 rencana penerimaan mengalami penurunan sebesar $12,8 \%$ dan Penerimaan PPN dikatakan tidak tercapai.

3. Rencana target penerimaan PPN tahun 2015 sebesar 337.007.226.139 dan realisasi penerimaan PPN sebesar 297.014.047.335 dengan pencapaian sebesar $88,13 \%$ selisih perbandingan dengan tahun sebelumnya yaitu sebesar 38,86 \% dan pada tahun 2015 rencana penerimaan mengalami kenaikan meskipun tidak besar yaitu sebesar 17,32\% dan Penerimaan PPN dikatakan tidak tercapai.

4. Rencana target penerimaan PPN tahun 2016 sebesar 343.689.551.000 dan realisasi penerimaan PPN sebesar 315.544.685.539 dengan pencapaian sebesar $91.81 \%$ selisih perbandingan dengan tahun sebelumnya yaitu sebesar 6,23 \% dan pada tahun 2015 rencana penerimaan mengalami penurunan yang cukup signifikan yaitu sebesar 32,63\% dan Penerimaan PPN dikatakan tidak tercapai.

Berikut ini bukti total penerimaan pajak pada KPP Pratama Sukabumi dari tahun 2012 sampai dengan tahun 2016 adalah sebagai berikut:

Tabel 2. Total Penerimaan Pajak KPP Pratama

\begin{tabular}{|c|c|c|c|}
\hline Tahun & $\begin{array}{c}\text { Total Penerimaan } \\
\text { Pajak }\end{array}$ & Target Tahun & Pencapaian \\
\hline
\end{tabular}

\begin{tabular}{llllc}
\hline 2012 & $563,258,963,882$ & $537,565,060,796$ & 104,78 & - \\
\hline 2013 & $620,001,693,511$ & $654,042,756,214$ & 94,77 & 10,08 \\
\hline 2014 & $734,686,063,202$ & $759,255,037,545$ & 96,77 & 18,50 \\
\hline 2015 & $896,899,936,497$ & $1,108,562,090,517$ & 80,91 & 22,08 \\
\hline 2016 & $1,015,703,291,664$ & $1,278,782,929,000$ & 79,43 & 13,25 \\
\hline
\end{tabular}

Sumber: Kantor KKP Pratama Sukabumi (2016)
Rumus yang digunakan untuk mengetahui selisih adalah sebagai berikut :

$$
\Delta=\underline{\mathrm{X}_{2}-\mathrm{X}_{1}} \times 100 \%
$$

$\mathrm{X}_{1}$

Sumber: Untung Sukardji (2014)

1. Rencana target penerimaan pajak tahun 2012 sebesar 537.565.060.796 dan realisasi penerimaan pajak sebesar 563.258.963.882 dengan pencapaian sebesar $104,78 \%$ dan pada tahun 2012 rencana penerimaan pajak dikatakan tercapai.

2. Rencana target penerimaan pajak tahun 2013 sebesar 654.042.756.214 dan realisasi penerimaan pajak sebesar 620.001.693.511 dengan pencapaian sebesar 94,77\% selisih perbandingan dengan tahun sebelumnya yaitu sebesar 10,08 \% dan pada tahun 2013 rencana penerimaan pajak dikatakan tidak tercapai.

3. Rencana target penerimaan pajak tahun 2014 sebesar 759.255.037.545 dan realisasi penerimaan pajak sebesar 734.686.063.202 dengan pencapaian sebesar 96,77\% selisih perbandingan dengan tahun sebelumnya yaitu sebesar $18,50 \%$ rencana penerimaan mengalami kenaikan meskipun tidak besar yaitu sebesar 8,42\% dan pada tahun 2014 rencana penerimaan pajak dikatakan tidak tercapai.

4. Rencana target penerimaan pajak tahun 2015 sebesar 1.108.562.090.517 dan realisasi penerimaan pajak sebesar 896.899.936.497 dengan pencapaian sebesar $80,91 \%$ selisih perbandingan dengan tahun sebelumnya yaitu sebesar 22,08\% rencana penerimaan mengalami kenaikan meskipun tidak besar yaitu sebesar $22,08 \%$ dan pada tahun 2015 rencana penerimaan pajak dikatakan tidak tercapai.

Rencana target penerimaan pajak tahun 2016 sebesar 1.278.782.929.000 dan realisasi penerimaan pajak sebesar 1.015.703.291.664 dengan pencapaian sebesar $79,43 \%$ selisih perbandingan dengan tahun sebelumnyapun mengalami penurunan yaitu sebesar $13,25 \%$ rencana penerimaan mengalami penurunan yaitu sebesar $8,83 \%$ dan pada tahun 2016 rencana penerimaan pajak dikatakan tidak tercapai.

Berikut ini adalah perhitungan analisis perbandingan total penerimaan pajak pertambahan nilai dengan total penerimaan pajak pada KPP Pratama Sukabumi selama lima tahun dari tahun 2012 sampai dengan tahun 2016: 
Tabel 3. Analisis Perbandingan Penerimaan Pajak Pertambahan Nilai dengan Total penerimaan Pajak pada KPP Pratama Sukabumi Tahun 2012 s.d. 2016

\begin{tabular}{ccccc}
\hline Tahun & $\begin{array}{c}\text { Penerimaan } \\
\text { Bruto PPN }\end{array}$ & $\begin{array}{c}\text { Total Penerimaan } \\
\text { Pajak }\end{array}$ & Ratio & $\begin{array}{c}\text { Naik/ } \\
\text { Turun }\end{array}$ \\
\hline 2012 & $\begin{array}{c}130.985 .026 . \\
405\end{array}$ & 563.258 .963 .882 & 23,25 & \\
\hline 2013 & $\begin{array}{c}175.968 .860 . \\
919\end{array}$ & 620.001 .693 .511 & 28,38 & 5,13 \\
\hline 2014 & $\begin{array}{c}213.881 .719 . \\
297\end{array}$ & 734.686 .063 .202 & 29,11 & 0,73 \\
\hline 2015 & $\begin{array}{c}297.014 .047 . \\
335\end{array}$ & 896.899 .936 .497 & 33,11 & 4,00 \\
\hline 2016 & $\begin{array}{c}315.544 .685 . \\
539\end{array}$ & 1.015 .703 .291 .664 & 31,06 & $-2,05$ \\
\hline Sumber: Kantor KKP Pratama Sukabumi (2016) & &
\end{tabular}

\section{Keterangan :}

1. Analisis perbandingan ini menggunakan tahun sebelumnya sebagai tahun pembanding agar dapat diketahui perkembangan penerimaan pajak secara periodik dan perubahan-perubahan setiap periodenya akan terlihat jelas. Tahun pembanding/tahun sebelumnya diperhitungkan $100 \%$

2. Tahun awal pada periode yang dianalisis tidak mempunyai nilai persentase karena tidak mempunyai tahun pembanding dan tidak bisa diberikan nilai $100 \%$ karena analisa ini tidak menggunakan teknik analisa trend dengan menggunakan tahun dasar sebagai tahun pembanding.

3. Data diatas adalah analisa perbandingan yang dinyatakan dengan ratio antara Penerimaan Pajak Pertambahan Nilai dengan Total Penerimaan Pajak di KPP Pratama Sukabumi.

Rumus yang digunakan untuk mengetahui ratio adalah sebagai berikut:

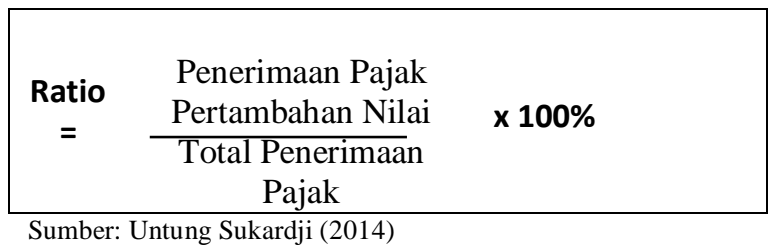

Berikut adalah cara perhitungannya :

1. Analisis jumlah realisasi penerimaan pajak pertambahan nilai dengan total realisasi penerimaan pajak tahun 2012

Rp 130.958.026.405

$$
\begin{aligned}
\text { Ratio }= & \frac{\operatorname{Rp~} 130.958 .026 .405}{\operatorname{Rp~} 563.258 .963 .882} \times 100 \% \\
& =23,25 \%
\end{aligned}
$$

a. Penerimaan Pajak Pertambahan Nilai Tahun 2012 sebesar Rp. 130.958.026.405.

b. Total Penerimaan Pajak Tahun 2012 sebesar Rp. 563.258.963.882.

c. Kontribusi penerimaan pajak pertambahan nilai terhadap Total Penerimaan Pajak pada tahun 2012 adalah sebesar 23,25\%

d. Belum dilakukan perhitungan naik/turun dari periode sebelumnya.

2. Analisis perbandingan jumlah realisasi penerimaan pajak pertambahan nilai dengan total realisasi penerimaan pajak tahun 2013

$$
\text { Rp 175.968.860.919 }
$$

$$
\begin{aligned}
\text { Ratio }= & \frac{\operatorname{Rp} 620.001 .693 .511}{\operatorname{Rp}} \times 100 \% \\
& =28,38 \%
\end{aligned}
$$

a. Penerimaan Pajak Pertambahan Nilai Tahun 2013 sebesar Rp. 175.968.860.919.

b. Total Penerimaan Pajak Tahun 2013 sebesar Rp. 620.001.693.511.

c. Kontribusi penerimaan pajak pertambahan nilai dengan total penerimaan Pajak pada tahun 2013 adalah sebesar $28,38 \%$.

d. Periode tahun 2013 mengalami kenaikan sebesar 5,13\% dari ratio periode pajak sebelumnya tahun 2012 .

3. Analisis perbandingan jumlah realisasi penerimaan pajak pertambahan nilai dengan total realisasi penerimaan pajak tahun 2014

$$
\text { Ratio }=\frac{\operatorname{Rp~213.881.719.297}}{\begin{array}{l}
\operatorname{Rp} 734.686 .062 .202 \\
=29,11 \%
\end{array}} \times 100 \%
$$

a. Penerimaan Pajak Pertambahan Nilai Tahun 2014 sebesar Rp. 213.881.719.297.

b. Total Penerimaan Pajak Tahun 2014 sebesar Rp. 734.686.062.202.

c. Kontribusi penerimaan pajak pertambahan nilai dengan total penerimaan Pajak pada tahun 2014 adalah sebesar $29,11 \%$.

d. Periode tahun 2014 mengalami kenaikan sebesar $0.73 \%$ dari ratio periode pajak sebelumnya tahun 2013 .

4. Analisis perbandingan jumlah realisasi penerimaan pajak pertambahan nilai dengan total realisasi penerimaan pajak tahun 2015

Rp 297.014.047.335

$$
\begin{gathered}
\text { Ratio }=\frac{}{\operatorname{Rp~} 896.899 .936 .497} \times 100 \%= \\
33,11 \%
\end{gathered}
$$


a. Penerimaan Pajak Pertambahan Nilai Tahun 2015 sebesar Rp. 297.014.047.335.

b. Total Penerimaan Pajak Tahun 2015 sebesar Rp. 896.899.936.497.

c. Kontribusi pajak pertambahan nilai terhadap Total Penerimaan Pajak pada tahun 2015 adalah sebesar 33,11\%.

d. Periode tahun 2015 mengalami kenaikan sebesar $4 \%$ dari ratio periode pajak sebelumnya tahun 2014.

5. Analisis jumlah realisasi penerimaan pajak pertambahan nilai dengan total realisasi penerimaan pajak tahun 2016.

$$
\text { Ratio }=\frac{\operatorname{Rp} 315.544 .685 .539}{\operatorname{Rp~} 1.015 .703 .291 .664} \times 100 \%
$$

a. Penerimaan Pajak Pertambahan Nilai Tahun 2016 sebesar Rp. 315.544.685.539.

b. Total Penerimaan Pajak Tahun 2016 sebesar Rp. 1.015.703.291.664.

c. Kontribusi pajak pertambahan nilai terhadap Total penerimaan Pajak pada tahun 2016 adalah sebesar 31,06\%.

d. Periode tahun 2016 mengalami penurunan sebesar $2,05 \%$ dari ratio periode pajak sebelumnya tahun 2015.

Gambar 1. Ratio Kontribusi PPN terhadap Total Penerimaan Pajak pada KPP Pratama Sukabumi

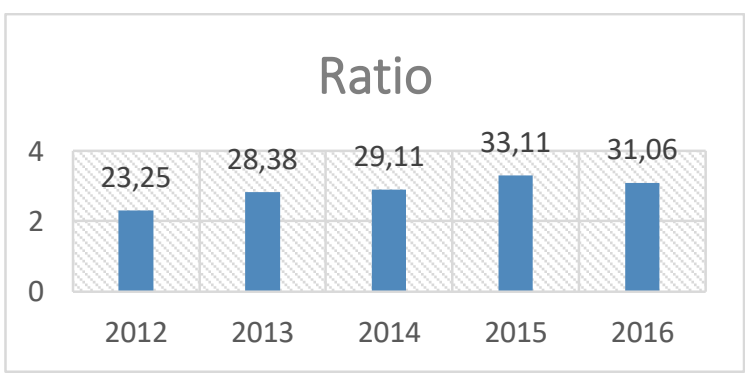

Sumber: Kantor KKP Pratama Sukabumi (2016)

Analisis perbandingan total penerimaan pajak pertambahan nilai dengan total penerimaan pajak pada KPP Pratama Sukabumi. Terdapat rasio perbandingan antara penerimaan PPN dengan total penerimaan pajak. Dimana rasio yang diberikan sudah stagnan dari waktu ke waktu dan kisaran rasio tersebut harus tetap dipertahankan. Karena rasio ini didapat dari pencapaian target yang telah diberikan. Maka agar rasio tersebut tercapai, kiranya perlu penggalian potensi perpajakan dengan lebih mendalam dan obyektif.

\section{KESIMPULAN DAN SARAN}

Berdasarkan hasil penelitian dimuka, peneliti dapat memberikan beberapa kesimpulan. Diantaranya adalah :

1. Realisasi Penerimaan PPN pada KPP Pratama Sukabumi selama 5 Tahun jika dirata-ratakan penerimaan PPN selama 5 Tahun adalah sebesar $109,99 \%$.

2. Realisasi Total Penerimaan pajak pada KPP Pratama Sukabumi selama 5 tahun jika dirataratakan total penerimaan selama 5 tahun adalah sebesar $91,34 \%$.

3. Analisis Perbandingan Jumlah Realisasi Penerimaan Pajak Pertambahan Nilai Dengan Total Realisasi Penerimaan Pajak Sebagai dasar dalam Menilai Pencapaian selama 5 tahun adalah sebesar $28,99 \%$ yang artinya bahwa $28,99 \%$ dari penerimaan pajak merupakan kontribusi atau penerimaan dari pajak pertambahan nilai.

Dengan menelaah hasil dari kesimpulan penelitian di atas, kiranya peneliti perlu memberikan beberapa saran sebagai masukan dimasa yang akan datang bagi objek penelitian, diantaranya adalah:

1. Penerimaan pajak pertambahan nilai pada KPP Pratama Sukabumi untuk 5 tahun terakhir sejauh ini sudah baik, namun masih harus mencari solusi bagaimana cara meningkatkan lagi target penerimaan PPN setiap tahunnya, bisa dari kegiatan konsultasi secara berkelanjutan dan kegiatan jemput bola, yaitu mendatangi Wajib Pajak yang sekiranya memiliki potensi pajak bernilai tinggi.

2. Total penerimaan pajak pada KPP Pratama Sukabumi untuk 5 tahun terakhir ini masih belum mencapai target. perlu ditingkatkan lagi dan dicarikan solusi apabila terjadi penurunan untuk total penerimaan pajak. Peningkatan dari pencapaian target bisa dilakukan dengan mensosialisasikan aturan-aturan baru perpajakan, serta melakukan kegiatan bimbingan dan pengawasan kepada Wajib Pajak dengan lebih menyeluruh dan merata.

\section{REFERENSI}

Anam, M. C., \& Andini, R. (2016). Melakukan Kegiatan Usaha Dan Pekerjaan Bebas Sebagai Variable Intervening ( Studi di KPP Pratama Salatiga ). Journal of Accounting.

Daud, A. (2018). Analisis Penerapan Pajak Pertambahan Nilai Pada PT. Nenggapratama Internusantara. Jurnal Riset Akuntansi Going Concern, 13(2), 78-87.

Hasan, W. A. (2018). Analisis Pelaporan Pajak Pertambahan Nilai (PPN) Pada PT. Bumi 
Mitra Buton Abadi. Jurnal Ilmiah Akuntansi Manajemen, 1 (November), 27-34.

Pemerintah Indonesia. (2007). Perubahan Ketiga Atas Undang-Undang Nomor 6 Tahun Perpajakan, Tentang Ketentuan Umum Dan Tata Cara Perpajakan. Jakarta: Sekretariat Negara.

Prayudi, D., \& Sejati, A. (2019). Rasio Jumlah Realisasi Penerimaan PPN Terhadap Total Realisasi Penerimaan Pajak (Pada KKP Pratama Sukabumi). Moneter, 6(2), 17-24.

Rambitan, C. (2019). Analysis Of The Application Of Income Tax Article 21 And Value Added Tax On PT . Emigas Sejahtera. Jurnal EMBA, $7(2)$.

Sugiyono. (2010). Statistik Untuk Penelitian. Bandung: Alfabeta.

Sukardji, U. (2014). Pajak Pertambahan Nilai. Jakarta: PT RajaGravindo Persada.

\section{PROFIL PENULIS}

Dicki Prayudi. Penulis merupakan lulusan pascasarjana Universitas Pasundan Bandung tahun 2016 jurusan Manajemen Pemasaran. Selama tiga tahun penulis bekerja di Bank Rakyat Indonesia sebagai Account Officer sampai tahun 2014. Penulis pun masih aktif mengajar di kampus Universitas Bina Sarana Informatika PSDKU Sukabumi dari tahun 2015. Selain mengajar, penulis juga aktif menjadi pembicara public speaking di event resmi dan grouping, seperti pengembangan public speaking Dinas Pariwisata Kota Sukabumi, Dinas Kesehatan Kota Sukabumi, dan lainnya.

Anisa Sejati. penulismerupakan lulusan Sekolah Tinggi Ilmu Ekonomi PGRI Kota Sukabumi lulusan tahun 2017 jurusan Akuntansi. Selama menempuh dunia perkuliahan, penulis bekerja di Kantor Pelayanan Pajak Pratama Kota Sukabumi sebagai administrasi officer. Tahun 2017 pun penulis memilih menjadi consultant pajak secara independen dan berstatus ibu rumah tangga. 